\title{
Potato Crop Suitability Site Selection for Food Security Using GIS with Mcda, in Amhara Region, Ethiopia
}

\author{
Mulualem Asfaw Ejegu* \\ Geography and Environmental Studies Department, Faculty of Social Science and Humanity, Debre Tabor \\ University, Ethiopia. \\ Received 25 August 2020, Accepted 01 October 2020, Published October 2020
}

\begin{abstract}
Potato is one of the most common food crops cultivated in Amhara region. However, the current production supply couldn't satisfy demands for this crop. As a result, effective method of assessing environmental suitability analysis to increase the production of this crop is needed. A multi factor spatial analysis can effectively assess the environmental suitability of an area for potato cultivation. However, there are no comprehensive spatial MultiCriteria Decision Analysis (MCDA) of agricultural land suitability analysis for the study yet. In an attempt to underscore its significance, this study conducted GIS and MCDM based land suitability analysis. This approach uses the combination of traditional MCDA and GIS technology. It involves identifying suitability factors, hierarchical organization, standardization, rating and ranking, and weighing the factors selected and finally implementing the suitability model. The evaluation criteria used are elevation, slope, soil, rainfall, temperature variations and poor crop management. They were collected from different government agencies. The ranking and weighting were conducted through pairwise comparison of variables using experts from Amhara Region Agricultural Research Institute. The weights of factors were estimated by computing Eigen values and Eigen vectors of experts' pairwise ratings of criteria using IDRIS tools. Different suitability maps were prepared by combining MCDA and GIS. IDRIS and ArcGIS 10.3 extension tools were used in this regard as they have the capacity to integrate these modules. Four suitability scenarios were developed using different standardization and combination methods. Using the suitability scenario method, finally physical land suitability analyses were conducted. The results of the analyses disclosed that large area of land on the highland plateau and plain of South Gondar, West Gojjam and Awi are suitable for potato crop cultivation. On the other hand, North Gondar and some part of East Gojjam are not suitable for potato growing.
\end{abstract}

Keywords: GIS, Remote Sensing, MCDA, Suitability, Eigen vectors

DOI: $10.7176 / \mathrm{JEES} / 10-10-01$

Publication date:October $31^{\text {st }} 2020$

\section{INTRODUCTION}

One of the concerns of today's societies is supplying an ever-growing population with food which is directly or indirectly related to agricultural products (Lal, 1994 cited in Jain, 2010). In this regard, scholars seek to find the most suitable arable land (Maron, 2007).

In Ethiopia about $85 \%$ of the total population resides in rural areas who engaged in agricultural activities as a major means of livelihood (CSA., 2013). However, agricultural productivity is low and unable to feed the rapidly growing population of the country (Rabia, 2012; Rabia A. , 2012 and Ayalew, 2015). Natural calamities, food insecurity and famine become the salient features and critical problems (FAO, 2011).

Potato has been considered as a strategic crop by the Ethiopian government aiming at enhancing food security and economic benefits to the country. Since as the population grows rapidly, increased productivity of potatoes can improve the livelihood of small holder potato farmers (CSA, $2002 \mathrm{citec}$ in Ayalew, 2015). So, improvement in potato production system can be a pathway out of poverty in Sub Saharan Africa, including Ethiopia (Bymolt, 2014)

Since, potato is an excellent smallholder farmers crop in the highlands, with in about 3-4 months cropping cycle and potentially gives 40 tons per hector (CSA, 2013). Potato cultivation is suitable for places like Ethiopia where land is limited and labor is abundant which serves as both a cash and food security crop ( (Atsbaha et al 2002 and Bymolt, 2014). Ethiopia in 2009, 0.94 million tons of potato tuber were produced nationally from 164,000 ha of land (CSA, 2003). So, Potato's production can fill a gap in food supply during the 'hungry months' of October to December before the grain crops being harvested (Haverkort, et al 2012 and Gildemacher, 2012).

However, currently only $2 \%$ of the potential area in Ethiopia is under potato production and the average productivity of potato is less than 10 ton per hector (EARI, 2006). The same is true for Amhara National Region state where most of the agricultural land suitable for potato is located which range from 1800-2500 m.a.s.l altitude and receive annual rainfall more than $600-1,200 \mathrm{~mm}$, (Yilma, 1991). Amhara Region contributed 36.1\% of the annual national potato production (CSA., 2013), where the regional average potato tuber yield (4.8 t/ha) is less than the national average yield (5.7 t/ha) (CSA, 2003).

Factors such as late blight (Phytophtora infestans) and bacterial wilt (Pseudomonas solanacearum) infections, 
poor crop management, and elevation, slope, soil, rainfall, and temperature variations contributed for the low productivity of potato in the region (Yihenew, 2014; Girma et al, 2015 and Tesfaye, 2016)). So, it is necessary to conduct land suitability analysis which provide information on the constraints and opportunities for the use of the land and improve productivity (Ahmad, 2012).

Realizing the potential of GIS technology and problems in agricultural systems, this study aims to undertake GIS and Multi-Criteria Decision Analysis(MCDA) based land suitability analysis to identify and map potential areas for potato cultivation in Amhara region.

\section{Materials and methods}

\section{Description of the study area}

Amhara National Regional State (ANRS) is one of the nine ethnic divisions (kililoch) of Ethiopia, containing the homeland of the Amhara people. The capital of the region is Bahir Dar, a vibrant city located in the southern shore of Lake Tana. The ANRS extends from $9^{\circ}$ to $13^{\circ} 45^{\prime} \mathrm{N}$ and $36^{\circ}$ to $40^{\circ} 30^{\prime} \mathrm{E}$. It is bounded by Tigray region in the north, Oromia region in the south, Benishangul-Gumuz region and Sudan and South Sudan in the west, and Afar region in the east. It covers $161,828.4$ sq. $\mathrm{km}$ area and is moderately compact in shape (CSA, 2007).

The ANRS is made up of eleven administrative zones, namely Wag Himra, North Gondar, South Gondar, North Wollo, South Wollo, North Shewa, Oromia Special Zone, East Gojjam, West Gojjam, Awi and Bahir Dar Special Zone. These zones are divided into a total of 113 districts and 3,216 Keeble's (http://www.ethiopia.gov.et/stateamhara accessed February, 2017).

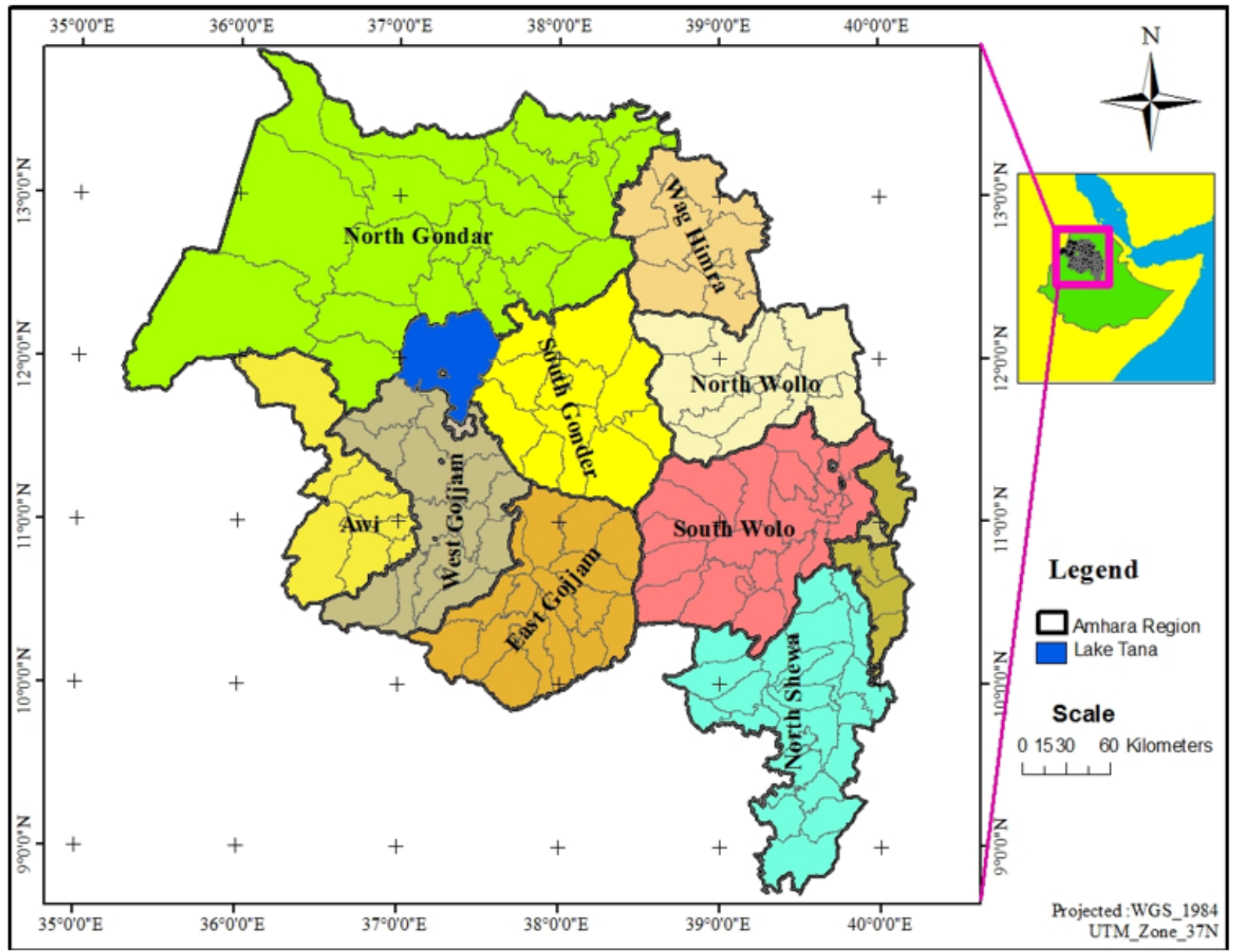

Figure 1: Map of Study area

Source Ethio_GIS 2 Data

\section{Methodology \\ Materials}

Materials and software used in the study were Arc GIS10.4, ERDAS 2015, and IDRSI to proses, analysis, combine the parameters and mapping potential suitable site of potatoes plantation areas, statistical package for social sciences (SPSS) to perform regression analysis and linear equation, DEM data with the spatial resolution of $30 \mathrm{~m}$ (resampled into $20 \mathrm{~m}$ ) used for elevation, slope and to generate temperature extraction and analysis. Soil data and 
minimum and maximum temperature data and MS excel to perform regression analysis.

\section{Data collection}

Almost all the data used in this investigation were secondary data such as rainfall data collected from 57 sampled metrological station and temperature data collected from 26 sampled places, and digital elevation model (DEM) with spatial resolution of 20 meters, and soil and slope data were used. In addition, other published (articles and books) and unpublished materials (reports and studies) were also used from different sectors.

\section{Data processing and analysis}

Data processing

DEM, rainfall, slope, soil and temperature data were processed by using ArcGIS 10.4, SPSS and MS excel by applying basic image preprocessing techniques starting from defining geodatabase, projection, and resampling cell size. Interpolation, regression, re-classification, weighted overlay and map algebra of GIS for spatial analysis technologies employed to select suitable site for the study area to get the final land suitability of potato vegetable crop. The factors that were considered for evaluation of the land suitability analysis of potato cultivation are elevation, slope, soil, rainfall and temperature. A GIS application was also employed for the purpose of managing, analyzing, combining and mapping suitable site selection of potato crop.

\section{Data analysis}

The Amhara region DEM data extracted from Ethiopia DEM data after extraction, this DEM data used for elevation, slope and to generate temperature data with regression analysis. The reaming rainfall data were generated using inverse distance weighted (IDW) interpolation in ArcGIS 10.4.

\section{Conceptual Framework}

The following dependent and independent variables were included in the study. The dependent variable was potato arable land while the independent variables were elevation (Buruso, 2017), slop (Buruso, 2017), soil type (Girma, etal 2015), rainfall and temperature (Atsbaha etal, 2002). All the variables are modeled below (figure, 5) by using ArcGIS model builder and the model is also validated and executed, the accuracy of the model was represented by the shadow of each model variable and parameter.

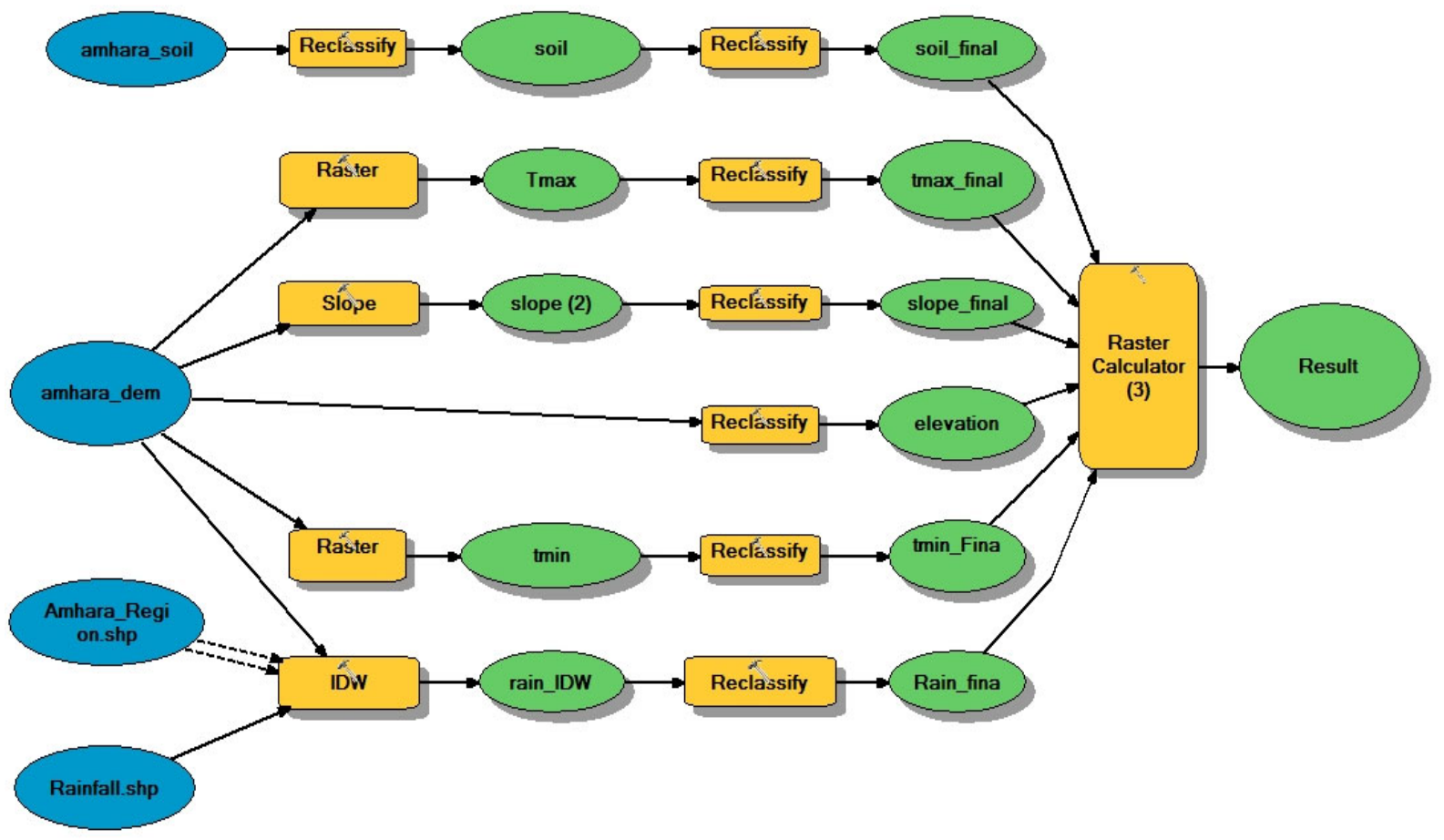

Figure 2: Conceptual framework diagram

\section{Result and discussion,}

Result

According to Ethiopia Agricultural Research Institute (2006), FAO Guidelines for Land Evaluation for Rainfed Agriculture (1998) FAO, Land Evaluation to ward a revised frame work, (2007), and ECACC(2002) the selection 
of suitable potential site for potato planting was prepared by analyzing elevation, slope, soil type, mean annual rainfall, extreme mean monthly minimum temperature and extreme mean monthly maximum temperature. Taking into account all this factors which influence cultivation of potato crop in Amhara Regional provinces, the map of potential potato cultivation areas was obtained.

\section{Suitable site of potato cultivation based on elevation}

The arrangement of the natural and artificial physical features of an area influences the suitability of potato plantation. The elevation of the study area ranges from $521-4378$ meters above sea level of which between 1500 to 3200 are suitable for potato plantation and below 1500 and above 3200 meter elevations considered as unsuitable because elevation affects the growth of crops indirectly by altitude and exposure to light and wind (EARI, 2006).

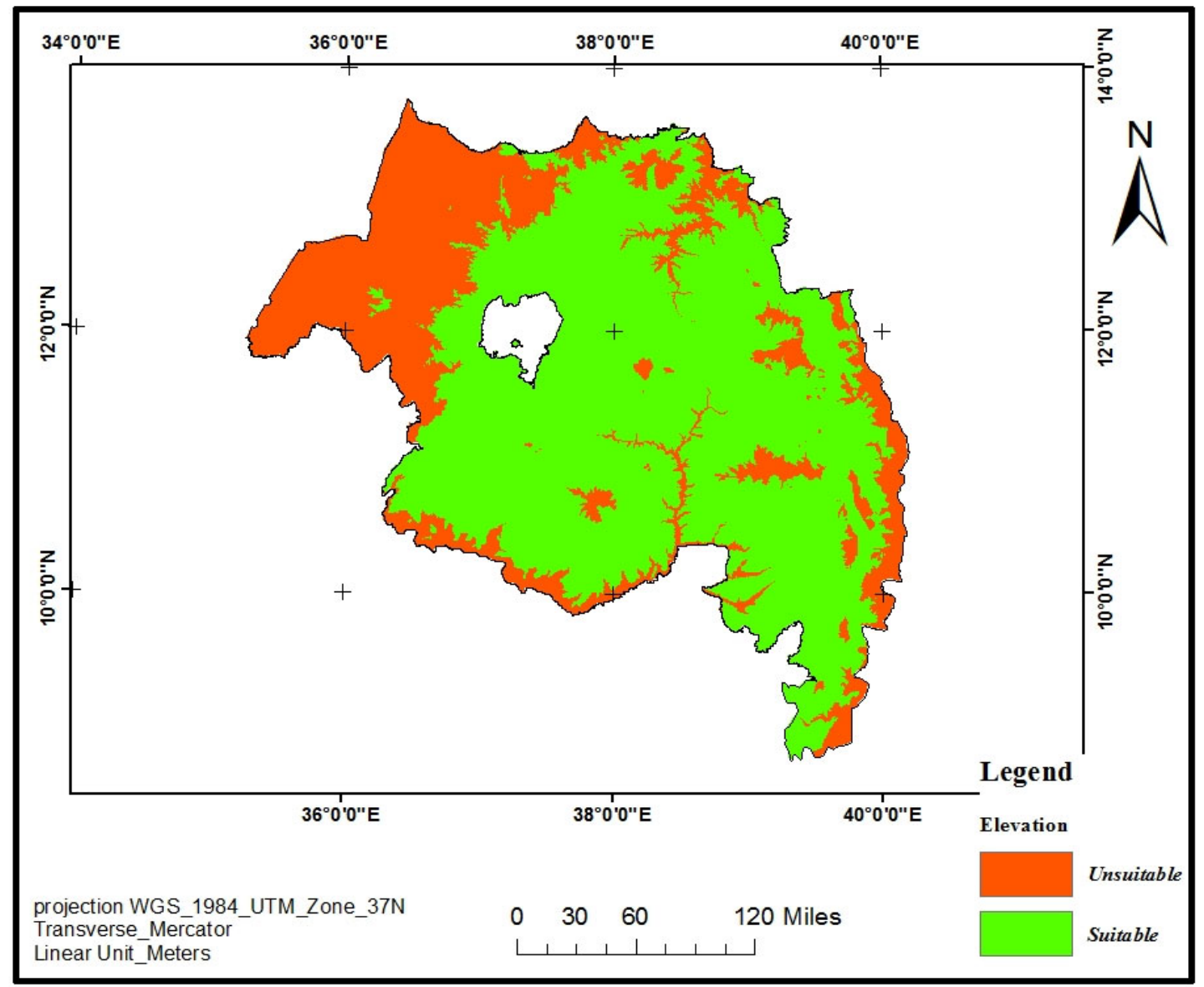

Figure 3: Suitable map of potato cultivation based on elevation.

Table 1: Suitability of potato cultivations based on elevation range.

\begin{tabular}{|c|c|c|c|c|c|}
\hline $\begin{array}{l}\text { Elevation } \\
\text { range }\end{array}$ & $\begin{array}{l}\text { Level of } \\
\text { suitability }\end{array}$ & $\begin{array}{l}\text { Codes assigned } \\
\text { on the map }\end{array}$ & $\begin{array}{l}\text { Color } \\
\text { represented }\end{array}$ & $\begin{array}{l}\text { Area coverage } \\
(\mathrm{sq} . \mathrm{km})\end{array}$ & $\begin{array}{l}\text { Percentage of area } \\
\text { coverage }(\%)\end{array}$ \\
\hline $521-1499.99$ & Unsuitable & 0 & Red & $44,583.72$ & 27.55 \\
\hline $1500-3200$ & Suitable & 1 & Green & 112292.73 & 69.39 \\
\hline $3200.99-4378$ & Unsuitable & 0 & Red & 4935.77 & 3.05 \\
\hline
\end{tabular}

In the above table, areas with altitude ranging from 521 -1499.99 meter above sea level and 3200.99 to 4378 meter above sea level are not suitable. But those areas with altitude ranging between 1500-3200 meter above sea level are suitable for potato cultivation. $69.39 \%$ area coverage of the study area elevation is suitable for potato cultivation, and the remaining $30.61 \%$ area are unsuitable for potato cultivation based on elevation.

\section{Suitability site of potato cultivations based on slope}

The slope of the study area ranges from 0 up to $62 \%$ and Ideal sites for potato production have slopes less than $20 \%$ and the land with greater than $20 \%$ slope consider unsuitable for potato cultivation because the risk of soil erosion is proportional to the length of the slope and the severity of the grade unless engineering conservation measures are require (Girma etal, 2015) (Ayalew, 2015) and (FAO and UNEP, 1999). 


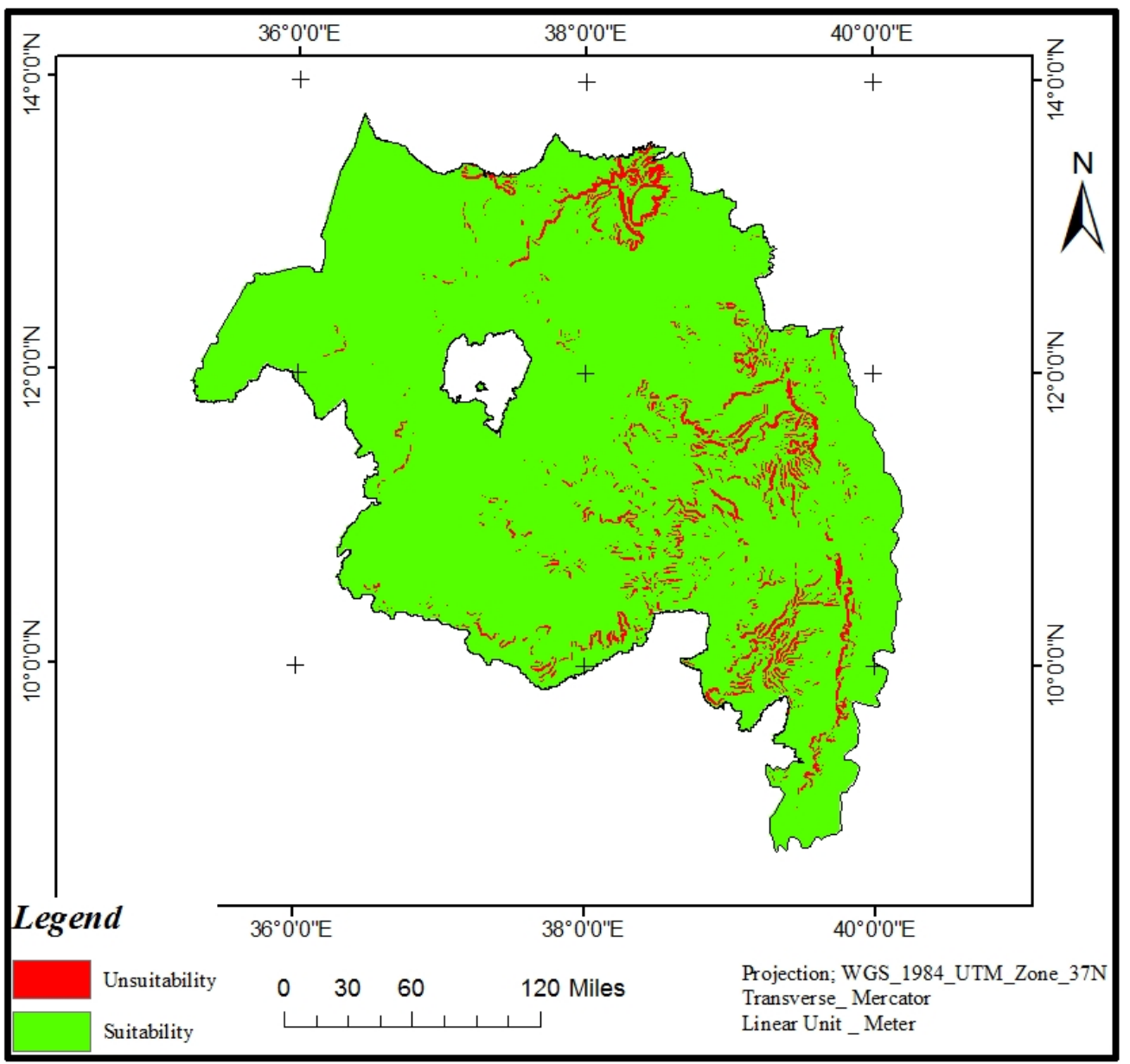

Figure 4:Suitable map of potato cultivation based on slope.

Table 2: Suitability and unsuitability values of slope with its range

\begin{tabular}{llllll}
\hline $\begin{array}{l}\text { Slope range } \\
\text { in percentage }\end{array}$ & $\begin{array}{l}\text { Level of } \\
\text { suitability }\end{array}$ & $\begin{array}{l}\text { Codes assigned } \\
\text { on the map }\end{array}$ & $\begin{array}{l}\text { Color } \\
\text { represented }\end{array}$ & $\begin{array}{l}\text { Area coverage } \\
(\mathbf{s q} . \mathbf{k m})\end{array}$ & $\begin{array}{l}\text { Percentage of area } \\
\text { coverage }(\%)\end{array}$ \\
\hline $\mathbf{0 - 2 0}$ & Suitable & $\mathbf{1}$ & Green & $\mathbf{1 5 2 8 1 4}$ & $\mathbf{9 4 . 4 3}$ \\
\hline $\mathbf{2 0 . 9 9}-\mathbf{6 2}$ & Unsuitable & $\mathbf{0}$ & Red & $\mathbf{9 0 1 3 . 8 4}$ & $\mathbf{5 . 5 7}$ \\
\hline
\end{tabular}

According to table 3,94.43\% coverage of the study area slopes were suitability for potatoes cultivation the remaining $5.57 \%$ were unsuitable for potatoes production.

\section{Suitability site of potato cultivations based on soil}

Soil type refers to the physical composition or properties of the soil (Steiner.f, L. McSherry, 2000). Soils basically consist of decomposed mineral matter (sand, silt, and clay) and decomposed organic matter and also some soil types tend to have poor aeration, drainage which restrict root growth (Yihenew and Selassie, 2014). Soil is the fundamental resource base for all agricultural production systems, soil quality influences its ability to provide an optimum media for growth, sustain crop productivity, maintain environmental quality, and provide for plant and animal health (Sheferawe, 2012). Therefore, soil quality and soil health are viewed as the foundation for successful organic production.

In the study area, greater than 100 major soil types present, potential potato productions are achieved on welldrained Lithosol, Nitosol and Cambsol soils types (Vassiliki etal, 1999)(Yihenew and Selassie, 2014). 


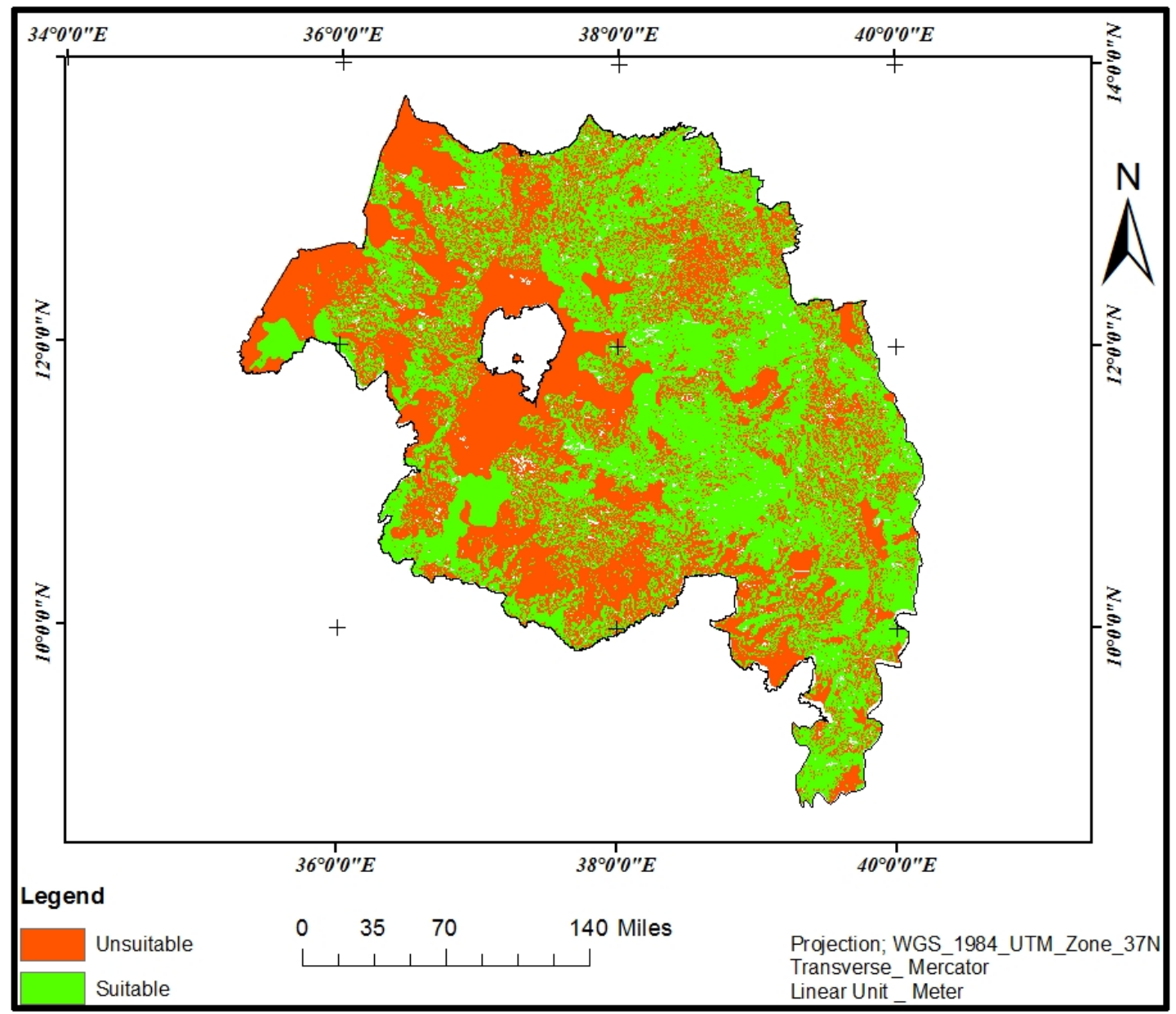

Figure 5: Suitable map based on soil type.

Table 3: Values of soil type based on suitable and unsuitable values.

\begin{tabular}{lllll}
$\begin{array}{l}\text { Level of } \\
\text { Suitability }\end{array}$ & $\begin{array}{l}\text { Codes assigned on the } \\
\text { map }\end{array}$ & $\begin{array}{l}\text { Color } \\
\text { represented }\end{array}$ & $\begin{array}{l}\text { Area } \\
\text { coverage } \\
\text { (Sq. Km) }\end{array}$ & $\begin{array}{l}\text { Percentage of Area coverage } \\
(\%)\end{array}$ \\
\hline Suitable & 1 & Green & 82467.75 & 50.96 \\
\hline Unsuitable & 0 & Red & 79360.65 & 49.04 \\
\hline
\end{tabular}

According to the map and table above the suitable soil types that are Cambsol, Lithosol and Nitosol that cover $27.82 \%, 9.43 \%$, and $13.71 \%$ respectively cover $50.96 \%$ of the study area; the remaining $49.04 \%$ covers unsuitable area.

Suitability site of potato cultivations based on mean annual rainfall

The seasonal requirement of mean annual rainfall for cultivation of potato in the study area at least 700 to 2600 $\mathrm{mm}$ of water. in some specific production areas depending on soil type, weather conditions, and other water engineering methods for potato cultivation (Sheferawe, 2012).

Therefore, an appropriate suitable site selection of mean annual rainfall between 700 to $2600 \mathrm{~mm}$ of the study area were taken. From the interpolated rainfall data, the study area means annual rainfall ranges from 194.502 up to $2659.26 \mathrm{~mm}$, within this range the suitable mean annual rainfall ranges from 700 up to $2600 \mathrm{~mm}$, and those below and above this range are unsuitable.

Table 4: Means annual Rainfall data based on suitable and unsuitable values.

\begin{tabular}{lllll}
\hline $\begin{array}{l}\text { Means annual } \\
\text { range }\end{array}$ & rainfall & $\begin{array}{l}\text { Level of } \\
\text { suitability }\end{array}$ & $\begin{array}{l}\text { Area coverage } \\
\text { (sq. } \mathbf{~ k m})\end{array}$ & $\begin{array}{l}\text { Percentage of } \\
\text { coverage (\%) }\end{array}$ \\
\hline $\mathbf{1 9 4}-\mathbf{6 9 9 . 9 9}$ & Unsuitable & 7897.23 & 4.88 \\
\hline $\mathbf{7 0 0}-\mathbf{2 6 0 0}$ & Suitable & 153866.44 & 95.08 \\
\hline $\mathbf{2 6 0 1}-\mathbf{2 6 5 9 . 2 6}$ & Unsuitable & 64.73 & 0.04 \\
\hline
\end{tabular}


As shown in Table 7, the suitable areas with mean annual fainfall ranging from $700-2600 \mathrm{~mm}$ constitute $95.08 \%$ of the total area. The remaining $4.92 \%$ areas are unsiutable which gets rainfall above and below the $700-$ 2600 rainfall amount.

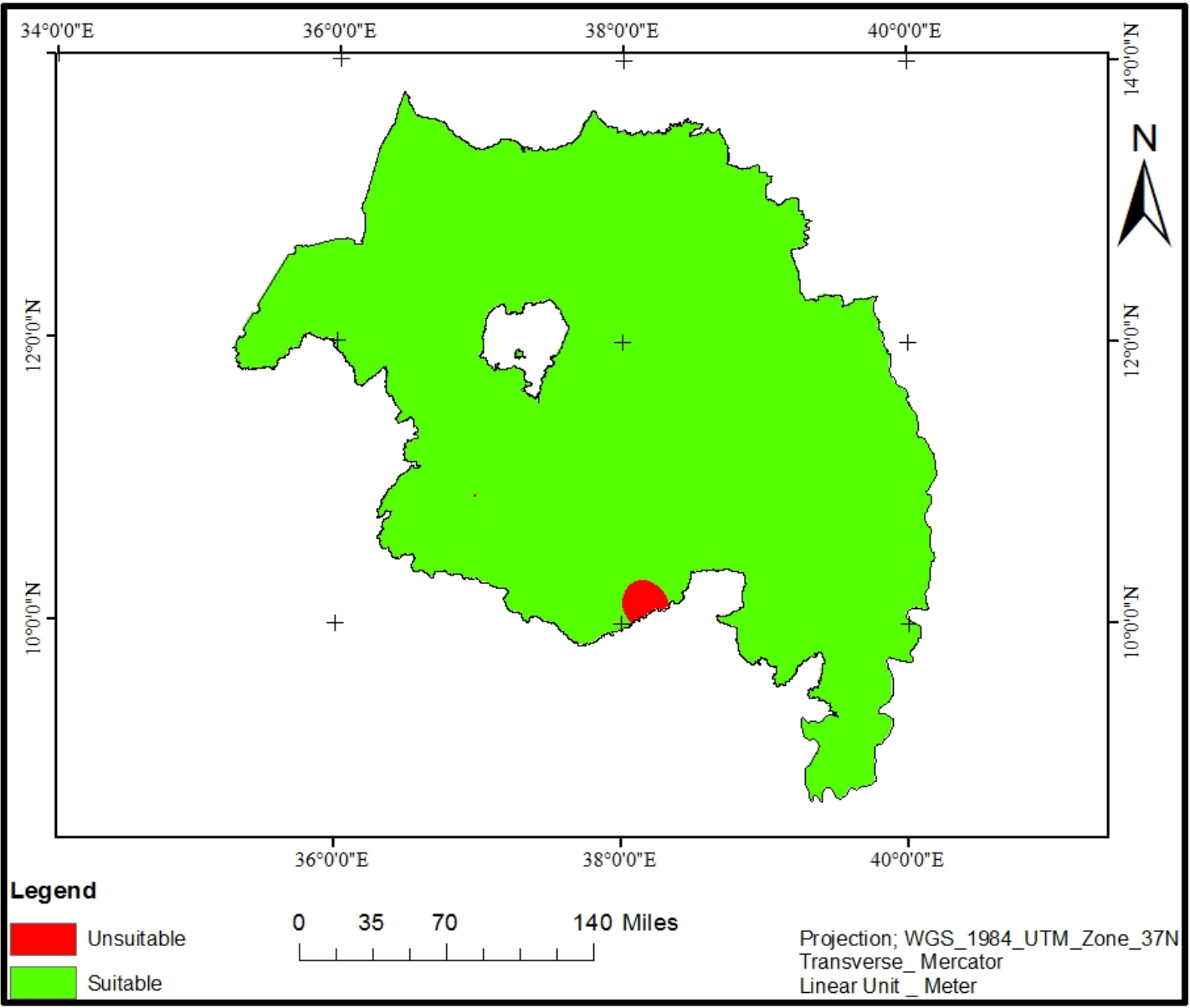

Figure 6, suitable map based on rainfall Means Annual Rainfall Range.

Table 5: Suitable and unsuitable values based on rainfall Means Annual Rainfall Range.

\begin{tabular}{lllll}
\hline $\begin{array}{l}\text { Level of } \\
\text { suitability }\end{array}$ & $\begin{array}{l}\text { Codes assigned on } \\
\text { the map }\end{array}$ & $\begin{array}{l}\text { Color } \\
\text { represented }\end{array}$ & $\begin{array}{l}\text { Area coverage } \\
\text { (sq. } \mathbf{~ k m})\end{array}$ & $\begin{array}{l}\text { Percentage of area } \\
\text { coverage } \mathbf{( \% )}\end{array}$ \\
\hline Suitable & 1 & White & 153866.44 & 95.08 \\
\hline Unsuitable & 0 & Black & 7961.96 & 4.92 \\
\hline
\end{tabular}

According to the map and the table $95.08 \%$ of area coverage is suitable for potato cultivation and gets enough amount of annual Rainfall Range and the remaining $4.92 \%$ coverage of the study area annual Rainfall are not suitable for potato cultivation.

\section{Suitability site of potato cultivations based on extreme mean monthly maximum temperature.}

The extreme mean monthly maximum temperatures below $29^{\circ} \mathrm{C}$ are very suitable for cultivation of potatoes (Girma etal, 2015) and (FAO, 1998). The extreme mean monthly maximum temperatures of the study area collected from 26 sample area within the study area, this data analyzed by using SPSS to get the regression equation of altitude and extreme mean monthly maximum temperature.

Table 6: The SPSS regression equation values extreme mean monthly temperature

\section{Coefficients'}

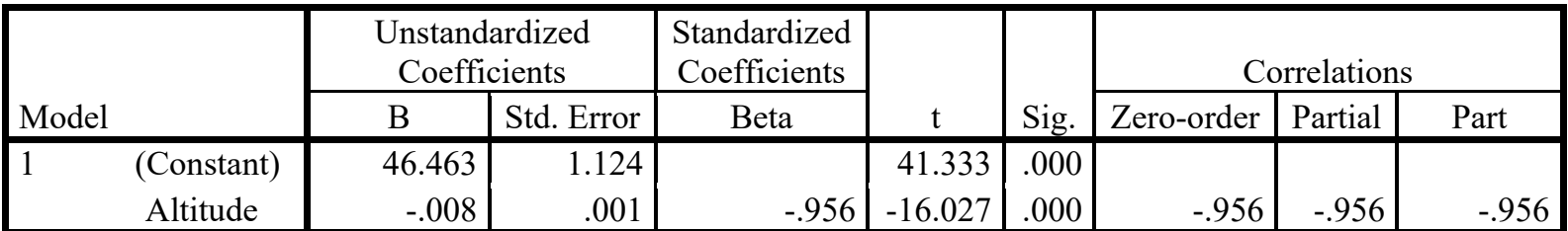

a. Dependent Variable: Tmax 


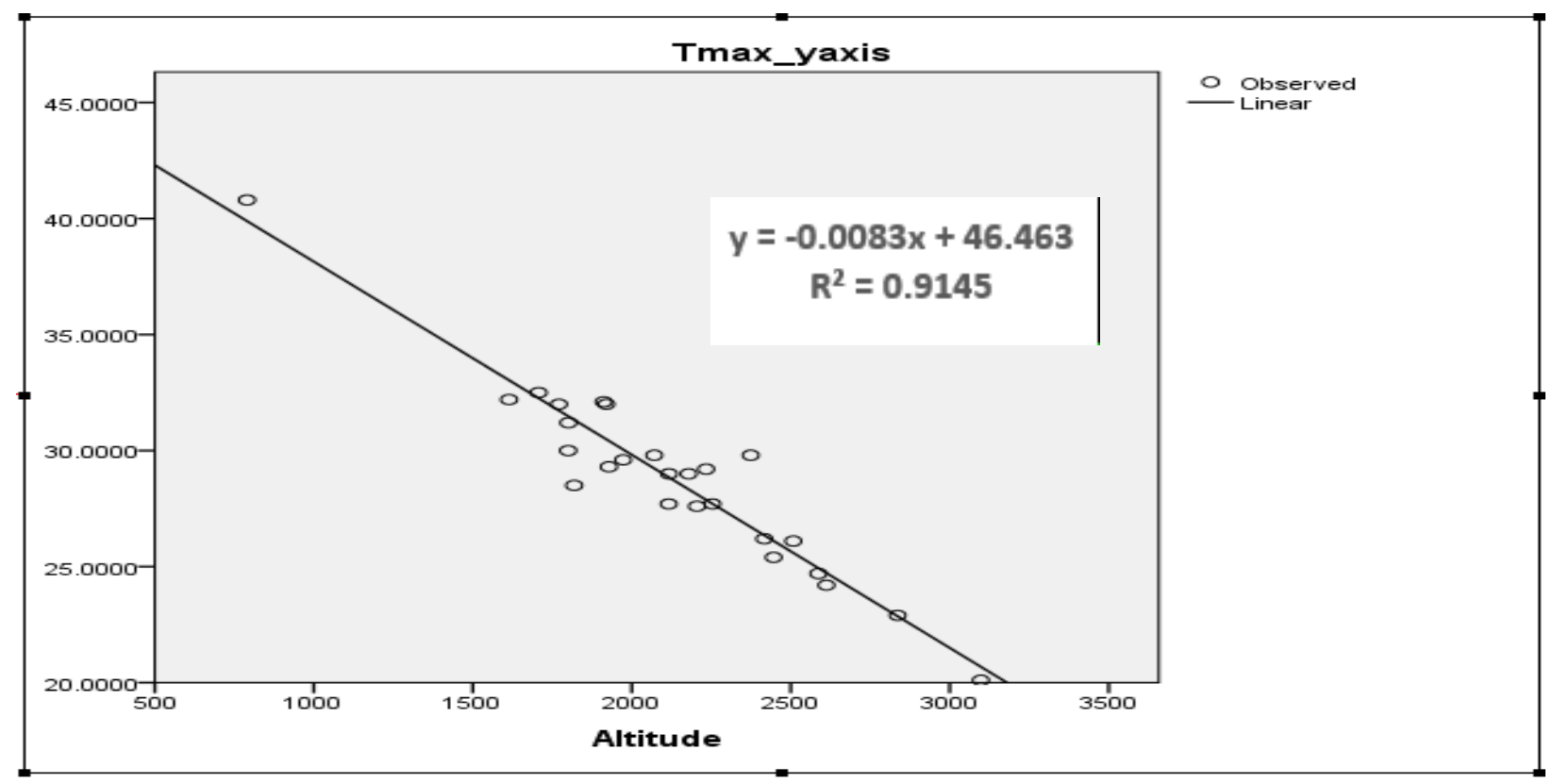

Figure 7: SPSS linear graph of altitude and extreme mean monthly maximum temperature.

From this linear graph extreme mean monthly maximum temperature and altitude have inverse relationships that means when altitude increases extreme mean monthly maximum temperature decreases and vise.

To estimate the extreme mean monthly maximum temperature suitable area, the regression value and coefficient equation was used and analyzed by using map algebra with DEM data and finally it generates a raster extreme mean monthly maximum temperature surface.

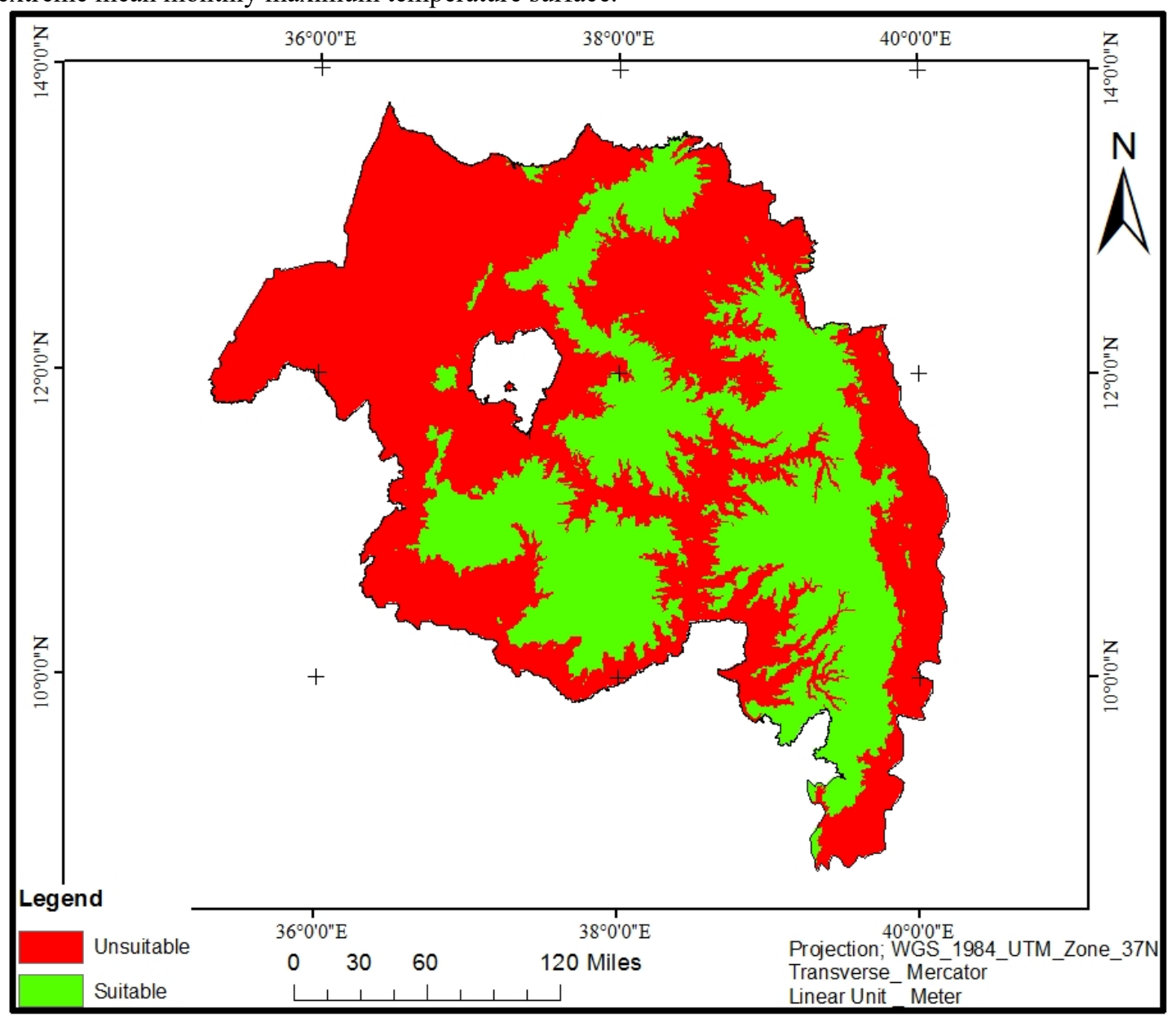

Figure 8, suitable map of extreme mean monthly temperature. 
Table 7: suitable and unsuitable values based on extreme mean monthly maximum temperature

\begin{tabular}{llllll}
$\begin{array}{l}\text { Extreme mean } \\
\text { monthly maximum } \\
\text { temperature. }\end{array}$ & $\begin{array}{l}\text { Level of } \\
\text { suitability }\end{array}$ & $\begin{array}{l}\text { Codes } \\
\text { assigned on } \\
\text { the map }\end{array}$ & $\begin{array}{l}\text { Color } \\
\text { represented }\end{array}$ & $\begin{array}{l}\text { Area coverage } \\
\text { (sq. Km) }\end{array}$ & $\begin{array}{l}\text { Percentage of } \\
\text { area coverage } \\
(\%)\end{array}$ \\
\hline $\mathbf{1 0 . 0 3 0 5 - 2 9}$ & Suitable & 1 & green & 61219.68 & 37.83 \\
\hline $\mathbf{2 9 . 9 9 - 4 2 . 1 2 7 2}$ & Unsuitable & 0 & red & 100608.72 & 62.17 \\
\hline
\end{tabular}

From the above result $37.83 \%$ area coverage of study area extreme mean monthly maximum temperature is suitable for potato production and the remaining $62.17 \%$ area coverage of study area extreme mean monthly maximum temperature is unsuitable for potato production and covers larger area.

Suitability site of potato cultivations based on extreme mean monthly minimum temperature

According to Ethiopia Agricultural Resarch Institute (2006) and FAO,(2011) cited in Ayalew, (2015) the extreme mean monthly minimum temperature above $7^{0} \mathrm{C}$ is very suitable for cultivation of potatoes. The extreme mean monthly minimum temperature is analyzed by using SPSS to get the regression equation of coefficient of altitude and Coefficient of extreme mean monthly maximum temperature.

Table 8, SPSS regression values of extreme mean monthly minimum Temperature.

\section{Coefficients}

\begin{tabular}{|c|c|c|c|c|c|c|c|c|}
\hline \multirow[b]{2}{*}{ Model } & \multicolumn{2}{|c|}{$\begin{array}{l}\text { Unstandardized } \\
\text { Coefficients }\end{array}$} & $\begin{array}{l}\text { Standardized } \\
\text { Coefficients }\end{array}$ & & & \multicolumn{3}{|c|}{ Correlations } \\
\hline & B & Std. Error & Beta & $\mathrm{t}$ & Sig. & $\begin{array}{l}\text { Zero- } \\
\text { order }\end{array}$ & Partial & Part \\
\hline $\begin{array}{cl}1 & \text { (Constant) } \\
& \text { Altitude }\end{array}$ & $\begin{array}{r}14.376 \\
-.003\end{array}$ & $\begin{array}{r}2.398 \\
.001\end{array}$ & -.470 & $\begin{array}{r}5.995 \\
-2.605\end{array}$ & $\begin{array}{l}.000 \\
.016\end{array}$ & -.470 & -.470 & -.470 \\
\hline
\end{tabular}

a. Dependent Variable: Tmin

As shown below, in the SPSS linear graph, when altitude increases extreme mean monthly minimum temperature decreases and vise verse. The coefficient equation and regression value of the SPPS analysis result was used to develop raster surface of extreme mean monthly minimum temperature.

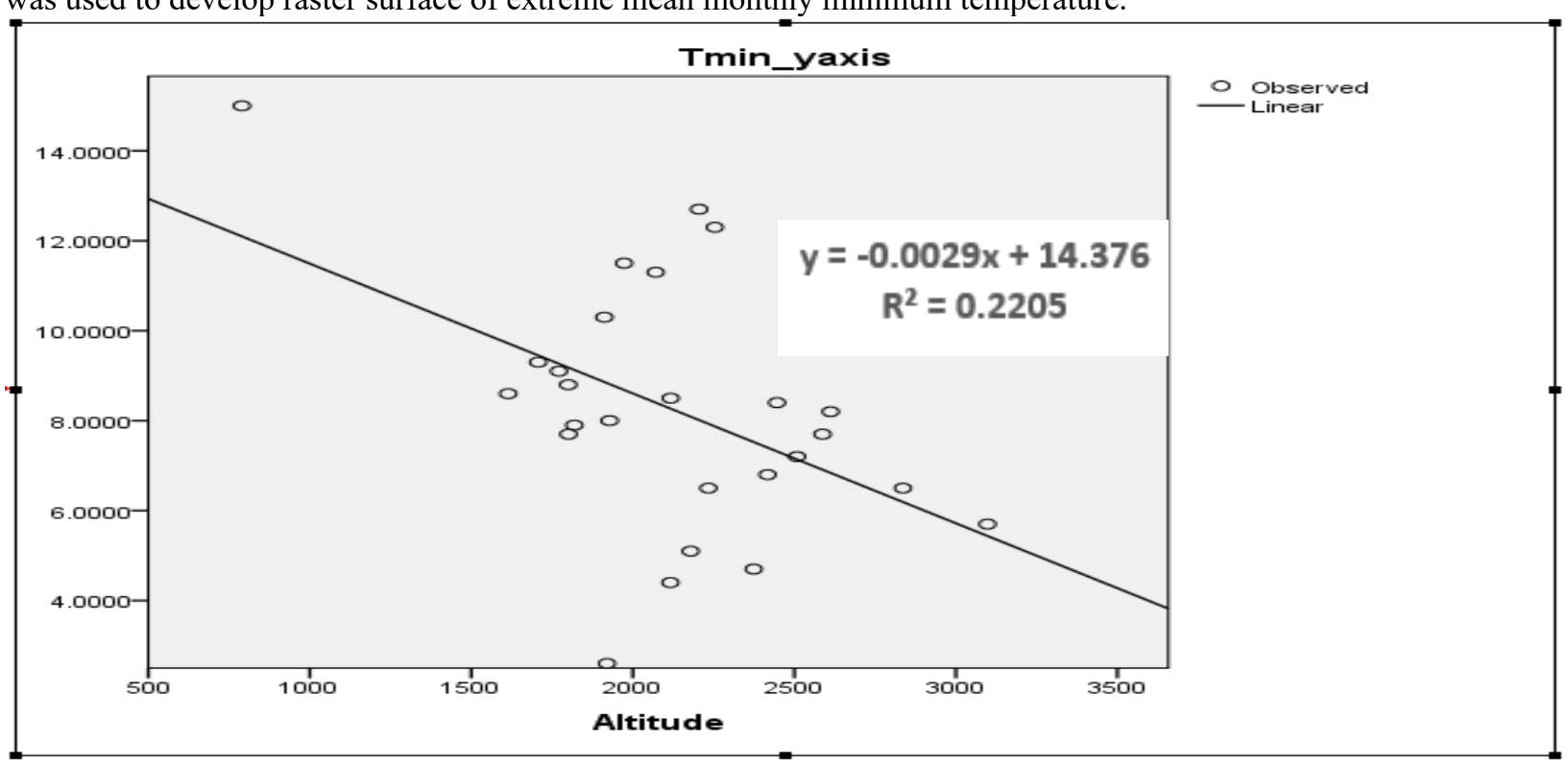

Figure 9: SPSS linear graph of altitude and extreme mean monthly minimum temperature. 


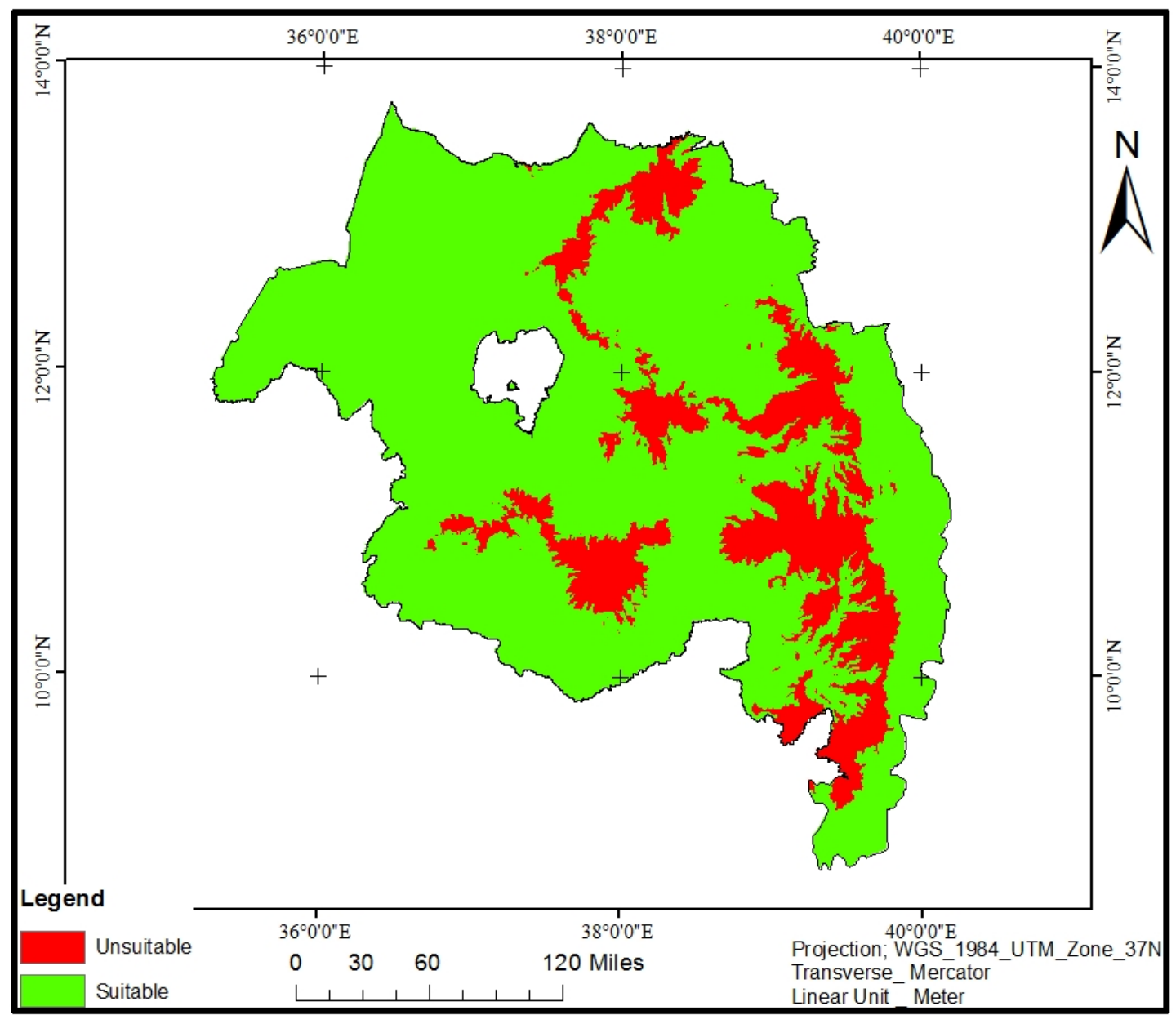

Figure 10, suitable and unsuitable values based on Extreme mean monthly minimum temperature

Table 9: Suitable and unsuitable values based on extreme mean monthly minimum temperature

\begin{tabular}{lllllll}
\hline $\begin{array}{l}\text { Extreme mean } \\
\text { monthly } \\
\text { temperature. }\end{array}$ & $\begin{array}{l}\text { Level of } \\
\text { suitability }\end{array}$ & $\begin{array}{l}\text { Codes } \\
\text { assigned } \\
\text { the map }\end{array}$ & on & $\begin{array}{l}\text { Color } \\
\text { represented }\end{array}$ & $\begin{array}{l}\text { Area coverage } \\
(\mathrm{sq} . \mathrm{km})\end{array}$ & $\begin{array}{l}\text { Percentage of } \\
\text { area } \\
(\%)\end{array}$ \\
\hline $1.7416-6.99$ & Unsuitable & 0 & green & 27607.93 & 17.06 \\
\hline $7-12.8728$ & Suitable & 1 & red & 134220.47 & 82.94 \\
\hline
\end{tabular}

According to the above result $82.94 \%$ area coverage of study area extreme mean monthly minimum temperature is suitable for potato production this covers the larger area of study area and the remaining $17.06 \%$ area coverage of study area extreme mean monthly minimum temperature is unsuitable for potato production and covers larger area.

\section{Discussion}

\section{Selection of potential potato growing areas}

After evaluating all the factors of suitability site selection of potato cultivation, operations of raster composition or map algebra and weight determination of each elevation, slope, soil, mean annual rainfall, extreme mean monthly minimum temperature and extreme mean monthly maximum temperature, and their combination was taken, and the final location suitable site selection of potato map for Amhara region was generated as follows. 


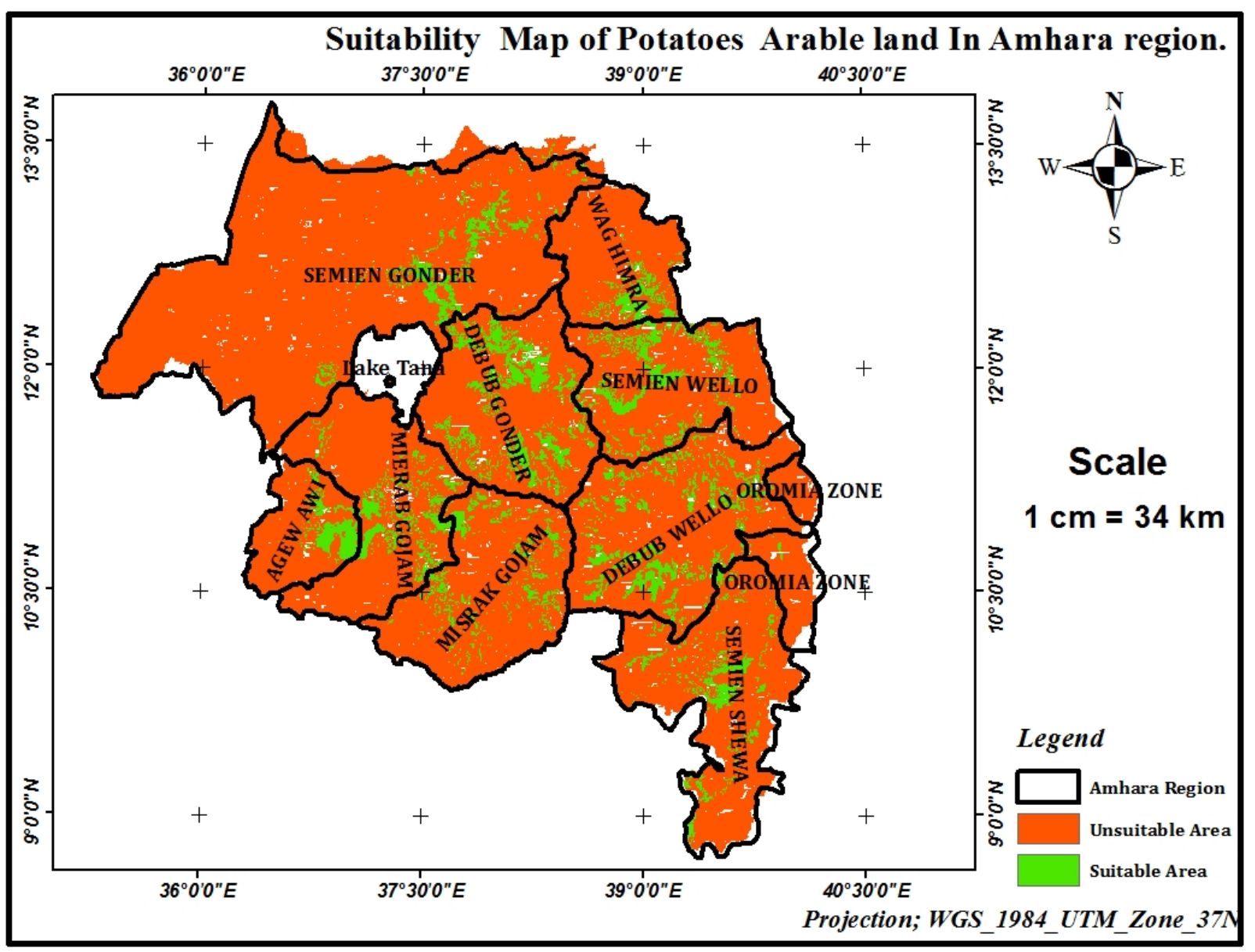

Figure 11: Suitable and unsuitable map of potatoes in Amhara Region

Table 10: Suitable and Unsuitable values of potatoes

\begin{tabular}{lllll}
\hline $\begin{array}{l}\text { Level of } \\
\text { suitability }\end{array}$ & Color represented & $\begin{array}{l}\text { Area coverage } \\
(\mathrm{sq} . \mathrm{km})\end{array}$ & $\begin{array}{l}\text { Percentage } \\
\text { coverage }(\%)\end{array}$ & area \\
\hline Suitable & Green & 16312.3 & 10.08 \\
\hline Unsuitable & Red & 145516.1 & 89.92 \\
\hline
\end{tabular}

According to the final potato suitable site selection map, which was generated from six variables that are elevation 1500 to 3200, slope less than 20\%, soil type Lithosol, Nitosol and Cambsol, mean annual rainfall 700 to $2600 \mathrm{~mm}$, extreme mean monthly minimum temperature above $7^{\circ} \mathrm{C}$, extreme mean monthly maximum temperature below $29^{\circ} \mathrm{C}$, existence of unsuitable area in the North-western parts of Amhara region is obvious. In this map, the red color spectrum represents inappropriate and undesirable region, and the green color spectrum indicates more suitable and arable land for potato cultivation. About 16,312.3 square kilometers of the study area, which accounts for $10.08 \%$ of Amhara region, are suitable land for potato cultivation the remaining 145,516.1 square kilometers of the region, which accounts for $89.92 \%$ of its total study area are unsuitable land for potato cultivation.

\section{Conclusions}

Based on the results of suitable site selection of potato in Amhara region, it can be concluded that, elevation, slope, soil, mean annual rainfall, extreme mean monthly minimum temperature and extreme mean monthly maximum temperature are the main factors that affect land suitability of potato cultivation. The results of the analyses prevailed that large area of land on the highland plateau and plain of South Gondar, West Gojjam and Awi are suitable for potato crop cultivation. On the other hand, North Gondar and some part of East Gojjam are not suitable for potato growing.

\section{References}

Abate, S. (2012). Land Suitability Evaluation for Sustainable Rainfed Agriculture in the Borena Woreda of South Wollo Highlands,Ethiopia:The Case of Legemara Watershed(Unpublished doctoral Dissertation). Addis Ababa Uniersity, Addis Ababa, Ethiopia. 
Akbari.v (2008). Landfill Site Selection by combining GIS and fuzzy Multi Criteria Decision Analysis a case study Bandar Abbas. Iran. Journal of Department of Surveying and Geomatics Engineering, p20, U university of Tehran, Iran.

ECACC. (2002). A Report on Preliminary Results of Area, Production and Yield of Temporary Crops (Meher Season Private Peasant Holding), Part II, on Ethiopian Agricultural Sample Enumeration. Addis Ababa, Ethiopia: Ethiopian Central Agricultural Census Commission (ECACC).

Atsbaha Gebre-Selassie and Tessema Bekele. (2002). A Review of Ethiopian Agriculture: Roles, Policy and Smallscale Farming Systems. Addis Abeba: Ethiopia Government.

Ayalew, G. (2015). A Geographic Information System Based Physical Land Suitability Evaluation to Groundnut and Sweet Potato in East Amhara, Highlands of Ethiopia. Journal of Biology, Agriculture and Healthcare ISSN 2224-3208 (Paper) ISSN 2225-093X (Online) Vol.5, No.1, 35.

Buruso, F. H. (2017). Habitat suitability analysis for hippopotamus (H. amphibious) using GIS and remote sensing in Lake Tana and its environs, Ethiopia. Buruso Environ Syst Res (2017) 6:6, 5.

Bymolt, R. (2014). Creating Wealth with seed. Amsterdam: Royal Tropical Institute.

CSA. (2007). 2007 Population and Housing Census of Ethiopia: Results for Amhara Region, Vol. 1. Addis Abeba, Ethiopia: Centeral Statistics Agency.

CSA. (2013). Agricultural Sample Survey 2012/13. Addis Ababa: CSA.

EARI, E. A. (2006). Food security. Addis Abeba: Ethiopia, Minster of Agricultural and Food security.

FAO. (1998). Guidelines: Land Evaluation for Rainfed Agriculture. Rome: FAO.

FAO. (2007). Land Evaluation to ward a revised frame work. Rome: FAO.

FAO. (2008). International Year of Potato. http://www.potato2008.org/en/world/index.html.

FAO. (2011). FAO Ethiopia Country Programming Framework 2012-2015. Addis Ababa: Food and Agriculture Organization of the United Nations.

FAO. (2011). FAOStat: Crops Production. http://faostat.fao.org/site/567/DesktopDefault.aspx? PageID $=567$ \#ancor.

FAO and UNEP (United Nation Enviromental Programme). (1999). The Future of Our Land Facing Challenge . Rome: FAO and UNEP.

Gildemacher, P. (2012). Innovation in Seed Potato Systems in Eastern Africa. Nairobi: Royal Tropical Institute.

Girma R, Moges A, Quraishi S. (2015). GIS Based Physical Land Suitability Evaluation for Crop Production in Eastern Ethiopia: A Case Study in Jello Watershed. Agrotechnol, 4.

Haverkort, A., Koesveld, F., Schepers, H., Wijnands, J.,Wustman, R., Zhang, Z. (2012). Potato prospects for Ethiopia: On the road to value addition. . Netherland: Wageningen UR.

(n.d.). http://www.ethiopia.gov.et/stateamhara.

Jain, S. K. (2010). Application of Meteorological and Vegetation Indices for evaluation of Drought Impact. National Hazards, 540, 643-656.

Lina, Z. and Wu, J. (2012). GIS-Based Multi-Criteria Analysis for Hospital Site Selection in Haidian District of Beijing. Student thesis, Master (one year),. Beijing, china.: 15 HE Geomatics.

Malczewski, J. (1999). GIS and Multi-criteria Decision Analysis. New York, USA: Wiley.

Maron, M. a. (2007). Agricultural intensification and loss of matrix habitat over 23 years in the West Wimmera, south-eastern Australia. Biological Conservation 135, 4.

Rabia, A. (2012). GIS Spatial Modeling for Land Degradation Assessment in Tigray, Ethiopia. 8th International Soil Science Congress on "Land Degradation and Challenges in Sustainable Soil Management", 161:167.

Rabia, A. H. (2012). A GIS based land suitability assessment for agricultural planning in Kilte Awulaelo district, Ethiopia. The 4th International Congress of ECSSS, EUROSOIL, Bari, Italy, 2.

Sewnet(PhD), A. (2014). Suitability analysis open lecture. Bahir Dar.

Sheferawe, A. (2012). Land Suitability Evaluation for Sustainable Rainfed Agriculture in the Borena Woreda of South Wollo Highlands,Ethiopia:The Case of Legemara Watershed. Addis Ababa Uniersity, Addis Ababa, Ethiopia: Unpublished doctoral Dissertation.

Steiner.f, L. McSherry. (2000). Land suitability analysis for the upper Gila River watershed. Landscape and Urban Planning .

Tesfaye, H. T. (2016). A Review on Potato (Solanum tuberosum L.) Production Situations in Ethiopia. Food Science and Quality Management, 32.

Vassiliki J. Kollias, Dionissios P. Kalivas. (1999). Land evaluation methodology and GIS for soil resource management. Example with cotton crop in Greece . Agronomie 19(1999) , 107-118.

Warsito Tantowijoyo and Elske van de Fliert. (2006). All about Potatoes. united State of Americ: Lembaga Pengembangan Teknologi Pedesaan.

Yihenew G. Selassie, G. A. (2014). Soil Characterization and Land Suitability Evaluation to Cereal Crops in Yigossa Watershed, Northwestern Ethiopia. Journal of Agricultural Science; Vol. 6, No. 5, 199. 